\title{
A Case Study of Emerging Challenges and Reflections on Internationalization of Higher Education
}

\author{
Nan Jiang ${ }^{1} \&$ Victoria Carpenter ${ }^{2}$ \\ ${ }^{1}$ Taylors's Business School, Taylor's University, Malaysia \\ 2 Derby Business School, University of Derby, United Kingdom \\ Correspondence: Nan Jiang, Taylor's Business School, Taylor's University, No.1, Jalan Taylor's, 47500, Subang \\ Jaya, Selangor Darul Ehsan, Kuala Lumpur, Malaysia. Tel: 60-03-5629-5673. E-mail: nan.jiang@taylors.edu.my
}

\author{
Received: June 3, 2014 Accepted: July 4, 2014 Online Published: August 17, 2014 \\ doi:10.5539/ies.v7n9p56 \\ URL: http://dx.doi.org/10.5539/ies.v7n9p56
}

\begin{abstract}
The purpose of this research was to examine challenges and issues of higher education (HE) internationalization. A qualitative study was conducted at a UK university. A total of 20 interviewees from the case study institution participated in this research. Content analysis, critical discourse analysis and categorization of meaning were adopted as data analysis strategies. The critical issues include resource and investment, workload, agent and partnership management, integration and cooperation, motivation and incentives, staff attitude and development. This study encourages an internal cohesion across different key departments, and emphasizes that HE internationalization is kind of an internal integration, rather than a set of external initiatives. Research findings reflect the university's critical internal concern of HE internationalization.
\end{abstract}

Keywords: higher education, internationalization, issues and challenges

\section{Introduction}

Higher education (HE) internationalization is defined as the "process of integration an international/intercultural dimension into the teaching, research and services functions of institutions" (Knight, 2004, p. 5). Internationalization of higher education has moved from the fringe of institutional interest, such as student exchange programs, to the core initiatives, for example, a big business of recruitment and academic collaboration over the past two decades (Brandenburg \& De Wit, 2011). "The process of internationalization affords many benefits to higher education, while it is clear that there are serious risks associated with the complex and growing phenomenon" (Knight, 2007, p. 9). This paper discusses the challenges of HE internationalization from the case study university's internal context and provides associated reflections in relation to the implementation of HE internationalization. First, a brief literature review of risks and challenges of HE internationalization presents the current examinations of HE internationalization, and a knowledge gap in this field is highlighted. Next, methodology addresses the research approach, data collection and analysis strategies, followed by a discussion of research findings and recommendations.

\section{Literature Review of HE Internationalization Risks and Challenges}

Although HE internationalization has evolved dramatically and experienced with tremendous growth, several challenges confronted and remained unsolved for long in the process of HE internationalization.

\subsection{Commercialization and Commodification of HE Internationalization}

The institutional trade in education services has become a multi-billion dollar business and a major source of income for many developed countries (Cheung et al., 2011). "Internationalization has been considered as the 'white knight' of higher education (compared to globalization)... and it has become a synonym of doing good" (Brandenburg \& De Wit, 2011, cited in De Wit, 2011, p. 29). It has been marketed by university as "a new indicator of excellence" (Harris, 2009, p. 348). However, there is less concern about the substance, outcomes and true meaning of HE internationalization, although some practitioners may have different points of view. For example, Sir Colin Campbell, the University of Nottingham's Vice-Chancellor states that overseas campuses are not all about money, but also about promotion opportunities for staff and students across the globe: " It is about how best to create opportunity for talented people-whatever their nationality, culture or social status." (Hodges, 2007, n.p cited in Jiang \& Carpenter, 2011, p. 149). Professor Drummond Bone, the University of Liverpool's 
Vice-Chancellor accentuates that Liverpool in China is not for the money, but to get Liverpool's name into the international market place (Ibid). Consequently, quality of education and research has been eclipsed by the economical rationale, and incrementally destroyed under the 'rightful' flag of internationalization. The public and social role of higher education has been deformed by the forces of commercialization, globalization, entrepreneurialism, marketing and competition. Higher education has been treated as a commodity, similar to raw materials and manufactured goods (Shubert, 2004; Naidoo \& Jamieson, 2005; Eldik, 2011). Even prestigious international associations also 'close one eye' and 'tacitly' approve the trade of education in international marketplaces. According to Brandenburg and De Wit (2011, p. 31), “... these concerns have come to the surface in the response of higher education organization around the world to the inclusion of education in the General Agreement on Trade and Services (GATS) of the World Trade Organization (WTO)".

\subsection{Internationalization of Curriculum}

Internationalization of curriculum is well recognized as an important indicator of HE internationalization (Huang, 2006; Elkin et al., 2008; Jones, 2008; Killick, 2009). A misconception emerges and implies that internationalization of curriculum equals HE internationalization (De Wit, 2011). It is too simplistic to view the two terms as synonymous. This misconception moves institutions' effort from the fundamental essentials of internationalizing curriculum, for example inclusion of overseas ideas in the programmes for domestic students and a melding of different cultural ideas, to an aggressive adaption of foreign international standards through partnership/collaboration. However, foreign international standards may not always be better than the local ones. The merger between local and foreign curriculum should be integrated as a diversified approach to add more credit to the outcome of HE internationalization. Next, many institutions and authors believe that a culturally diverse student population can enhance the development of international curriculum and facilitate cross-cultural group experience as the international student population can be considered a source of knowledge, cultural sensibility, richness and diversity (Seymour, 2002; Lee \& Rice, 2007; Bamford, 2008; Lowe, 2008). However, curriculum internationalization is not a necessary outcome of a diverse student body. Internationalization should be considered as a journey, process or set of means, rather than the ultimate goal. Actually, some local students are not keen to interact with international students due to language, cultural or perceptual barriers (Thorstensson, 2001; Pritchard \& Skinner, 2002; Bakalis \& Joiner, 2004; Yen \& Stevens, 2004). Finally, similar international curriculum adopted erodes the local autonomy and identity, and makes foreign curriculum stands a better chance to succeed. For example, the popular MBA curriculum offered by most business schools is criticized as a 'cash cow' subject that focuses too much on theoretical/analytic models and reductionism (Schoemaker, 2008; Thomas \& Cornuel, 2012). The homogenization of international curriculum is not well suited to handle the difference, ambiguity and high rate of change in today's industries. Curriculum internationalization should have a more critical and evaluative content to embrace international studies. Therefore, the aforementioned belief of curriculum internationalization may just remain a deal.

\subsection{Management Diversity}

Management diversity has become a key challenge brought about HE internationalization due to linguistic, social and cultural barriers (Maringe et al., 2007; Maringe, 2009; Boyle et al., 2012). Two types of diversity emerge in HE internationalization: student diversity and staff diversity. Firstly, student diversity stems from international student exchange programmes, such as ERASMUS and SOCRATES, and cross-border recruitment. Student diversity is a straightforward and expected outcome of HE internationalization, although it can put pressure on home institutions in terms of student service, learning outcome, study experience, and balance between local and foreign students (Jiang \& Carpenter, 2013). Next, staff diversity refers to the "systematic and planned commitment by institution/organization to recruit, retain, career development, reward, and promote a heterogeneous mix of employees" (Ivancevich \& Gilbert, 2000, p. 75). International collaboration and establishment of overseas branch campuses stimulate staff diversity, mobility, and interaction, but also raise barriers between native and foreign staff. Foreign employees may remain an easy target for prejudice and institutional discrimination (Liff, 1999; Barbosa \& Cabral-Cardoso, 2007), and 'sameness' tends to prevail over 'difference' (Liff \& Wajcman, 1996). Foreign staff have to develop unilateral effort to fit into the institution, while institutions may not make sufficient effort to accommodate these foreign individuals. Although the benefits of a diversified workforce were acknowledged, little respect for diversity was detected in practice. Unlike student diversity, the issue of staff diversity remains considerably under-researched in HE internationalization.

Many studies have addressed others risks and obstacles of HE internationalization, such as quality assurance (OECD, 2004; Knight, 2007, 2008; Bataeiineh, 2008; De Wit, 2011), governmental policy and international competition (Altbach \& McGill, 1998; Maringe, 2009), more pressure on academic accreditation and recognition 
of qualifications due to various education systems and national legislation (Teichler, 1996; Teichler \& Maiworm, 1996; Van Damme, 2001; Jiang \& Carpenter, 2013), loss of cultural or national identity, especially in the Middle East and Latin America (IAU, 2005; Knight 2007), individual and development commitment (Audenhove, 1998; Brown, 1998). But the examination of literatures does not comprehensively present a more specific, complex, and changing reality from an institutional internal context. Research in similar areas either concentrates on the overall challenges of HE internationalization (Hodges, 2007; Knight, 2005, 2007; Harris, 2008, 2009; Maringe, 2009; Brandenburg \& De Wit, 2011; De Wit, 2011; Eldik, 2011), or is based on quantitative surface studies (Teichler, 1996; Teichler \& Maiworm, 1996; Van Damme, 2001; IAU global survey, 2005; GATE survey, cited in Sidhu, 2007; Niser, 2010), which lacks in-depth analysis and explanation of particular problems. Different concerns may emerge when investigation is undertaken within an institutional context. More issues may need to be added to the list of challenges of HE internationalization.

\section{Methodology}

\subsection{Sample Selection and Procedure}

The top universities in league table are not represented in this research as their brands and reputation are considered a sound credited asset. Therefore, there is less pressure for these institutions to recruit foreign students or expand their international markets. This research selected a UK university as a single case study to represent the majority of UK institutions whose international development is less advanced. This sample selection makes the research findings more likely to be transferable and applicable to other similar cases. Although the principal researcher is not an internal academic at the case study university, her overseas study experience provides an opportunity to witness the issues and challenges of HE internationalization. Therefore, it maintains a more objective perspective in this study. The secondary author, while internal to the institution, is not directly involved in internationalization. Case study is on a constructivist paradigm (Stake, 1995; Yin, 2003) that claims that truth is relative and it is dependent on one's perspective. Constructivist can help researchers to recognize the importance of subjective human creation of meaning from respondents, but does not reject outright some notion of the objectivity (Baxter \& Jack, 2008, p. 545). Constructivism is a premise of a social construction of reality, which builds up a closer collaboration between researchers and participants; therefore it could encourage the participants to talk more about their stories. At the same time, the researchers can better understand the respondents' actions and their connotative meaning of the reality (HE internationalization).

\subsection{Sample Size and Characteristics}

Based on the positions and job responsibilities, a total of 20 interviewees from three key departments (corporate, marketing, and faculties) were selected. The three interview groups were the corporate group-the planners, who are senior management in charge of advancing the university's strategic plan; the marketing group-the supporters, who coordinate across different departments in charge of international recruitment, partnership and student support; and the faculty group-the academic teaching teams, who are responsible for strategy implementation. With respect to interviewee selection, there is always a possibility of bias, especially in qualitative study, such as members of staff self-selecting to participate in the interviews with an individual purpose to give answers either to promote a point of view or to force an issue. In order to limit bias, this research collects data from three different sources (interviews, observation and secondary data) and adopts triangulation, participant observation, ethnography research strategies and critical discourse analysis to compare and evaluate the value of data collected. Due to job scope and responsibilities, it was impossible for each interviewee to know well all the international initiatives and activities at the case study university; therefore the focus group technique was used. This technique enables the researchers to better understand why different departments feel the way they do (Cohen \& Manion, 1992). The findings from each group were used to triangulate with other groups, which enhances validity and credibility of research findings.

The interview questions were pilot tested twice for ambiguity and clarity. Semi-structured interview plays a primary role in data collection on a 1:1 basis. Each group answers the same set of interview questions. The original interview transcript was a total of 329 pages, containing 20 interview records collected over the period of six months.

\subsection{Data Analysis Strategies}

Data analysis was conducted by four strategies, including content analysis, critical discourse analysis (CDA), categorization of meaning, and color coding. Since the interview transcript is primarily considered denotative meaning, content analysis (Stemler, 2001) was adopted to identify the focus of individual and group attention, and examine large volume of data in a systematic fashion with relative ease. However, content analysis uses word frequency count to make inferences about the matters of importance (Chandler, 1998), thus the application 
of content analysis is limited for qualitative studies, where an item occurring frequently in a text is not necessarily significant. Therefore, this research used critical discourse analysis (CDA, Fairclough et al., 2004) to examine the latent connotative meaning, such as the interviewees' underlying subjective views of HE internationalization, particularly when there was no transcript gained due to interviewees refused or were reluctant to answer certain questions. Categorization of meaning (Kavale \& Forness, 1996) analyses and categorizes primary data into sub-patterns, which was compatible and complementary to data reduction and summary. Finally, color coding of transcripts (Strauss \& Corbin, 1990) was used to identify the most frequently mentioned issues and to develop sub-themes and patterns from lengthy passages.

\section{Results}

First, every respondent was required to answer the same question: "What is internationalization strategy of University $[X]$ ?" This question examines the interviewees' understanding of international strategy at the case study university. The answers to this question concentrated on related activities or process of HE internationalization, such as dealing with the international initiatives, student recruitment, staff mobility, establishment of academic collaboration, and internationalization of curriculum. The findings highly correspond with the current discussion of HE internationalization, but partially reflect a misconception, where the means of internationalization (such as strategy, activity, process and initiative) appear to have become the goal of internationalization. Next, each interviewee was required to address the key question: "During the process of internationalization, what are the issues and challenges you face?" This question investigates the problems of HE internationalization based on the respondents' individual experience. It seeks the interviewees' view on three cognitive levels: informative, analytic and evaluative. Issues raised in the case study include resource and investment, workload, agent and partner management, integration and cooperation, motivation and incentives, staff attitude and development. The summary of research findings are presented as follows:

\subsection{Resource and Investment}

The resource issue at the present case study university emerges into two terms. The first term reflects a misalignment of resource among the three key departments. Both marketing and faculty departments agree that current resources are insufficient for internationalization:

"The involvement in marketing is difficult. Because it's expensive, it's a bit of a barrier."

Marketing interviewee

"It's very difficult to develop some subjects, for instance, biology and geology at an international level, because of the budgets...So we need a much longer-term strategy to enable the subject areas to budget for that, and for the faculty to budget for it."

Faculty interviewee

In contrast, the corporate group considers resource less of an issue because "[w]e should have planned that (resource and budget)":

"We shouldn't have (resource issue) because all of our overseas activity has to be fully costed before we start. So we have a very sophisticated system of estimating what the cost of delivery will be."

Corporate interviewee

The reason of this discord may be that the corporate group is not a strategy operator, but a strategy planner. They may hand off the 'ball' of implementation to other departments for execution. The corporate group only agrees that there is a resource challenge if the students are suddenly over-recruited: 
"If you suddenly had a lot more students than you were expecting... you might not have the people (academics)

in place on day one because you did not expect 200 students instead of 50."

Corporate interviewee

The second term of resource issue does not focus on whether the current resource is adequate, but on the university's investment into international initiatives. A marketing interviewee stresses that the university hesitates to invest in internationalization; and if the investment were made, a quick return on investment (ROI) would be expected:

"There was a head of international who had just persuaded the Finance Director to invest a little bit of money in getting a couple more staff... So the [---] had this sense that he'd spent a lot of money on internationalization already and...[international developments] weren't turning up ...there's that kind of belief in senior management for a while that they had invested heavily and it wasn't working...actually, they haven't invested heavily... and do not realize it (HE internationalization) would take several years to build up to awareness and all the rest of it."

Marketing interviewee

From the above remarks, it is evident that the senior management expects a quick return and does not fully appreciate how long it may take to implement the strategy. If that is the case, then most international objectives and initiatives will remain rhetoric with little chance for success.

\subsection{Workload}

Work overload is one of the main challenges faced by academics during the process of HE internationalization. All interviewees realize that international initiatives could be an additional work by faculties because most academics see teaching and research as their main responsibilities. Therefore, the corporate group suggests a flexible schedule, while stressing that internationalization is part of academics' work:

"We have to work with staff to say well, we will give you time for doing this extra activity, so you don't feel it's another job on top of the job you have got now. It's part of your job, they (foreign partners'students) are all University [X] students, wherever they happen to be and they're on your module, so you have to look after them. That can be a challenge but it's important to meet it."

Corporate interviewee

Unfortunately, the flexible schedule given by the senior management does not seem to work. HE internationalization continues to bother the faculties:

"Obviously, it (internationalization) creates an additional load on us (academics) which is not being planned into our work schedules... These things have a habit of appearing, and you have to take them on board." 
Unlike the above two groups (corporate and faculties), the marketing group views this challenge from an external partner's standpoint and highlights the importance of internationalization:

“Workloads, time, the fact that if you (academics) are under pressure and the people (partners and partners' students) are still there... The partners were a very small percentage of what we (University [X]) did, but we were a hundred percent of what they do, and that was a real mismatch."

Marketing interviewee

Workload has created a drain on faculties during the process of HE internationalization, while obviously the other two departments are not in the faculty's 'shoes'.

\subsection{Agent and Partnership Management}

Agent management in HE internationalization challenge marketing and corporate groups in various ways. Extreme and deceptive tactics were widespread, and acts of outright fraud were not unusual, such as dealing with fake qualifications and dishonest applications from overseas agents:

"Certainly I think [country] is very bad for fake qualifications. People make them (fake qualifications) on their word processor on their computer and try and send them through, so we have to have a lot of checking... There has been a risk that some agents help their customers by claiming to have IELTS scores that they haven't got. They might be trying to push the students through... So I think we try to be very vigilant on that side of things ..."

Marketing interviewee

Furthermore, there is not an appropriate mechanism for the home university to help their prospective students who may have been victims of fraud practice. However, some agents' activities may remain undetected for long, which could confuse the students and even affect the home university's reputation:

"Sometimes, you find the agents are charging the students to do certain things that should be free. So they (agents) think well, I (agent) will write a letter to University [X] to see how your (student's) application is going and that'll be \$200. You (prospective student) don't have to pay somebody to do it for you. If you're not confident about doing it, I suppose you are paying for a service, aren't you? But there's that slight uncertainty about whether the student thinks they are paying the University $[X]$ for those things or whether they know they're just paying the agent and it's not guaranteed." 
Although agents' activity is out of the scope of the university's control. In most cases, the home university has to mainly rely on agents to boost the international student recruitment because using agents is more cost-efficient compared to other approaches, such as establishment of academic partnerships and overseas campuses. Although direct applications to the home university are strongly encouraged, due to lack of ground support or self-confidence, many foreign students may still seek agents' assistance with their applications.

In addition, partner identification and development challenges the case study university as the partner institutions may have different goals or have difficulties to obey each other's regulations:

"Identifying suitable partnerships is always a challenge. You have to be wary of the offers you're made because, anybody will make as good a claim as possible and you've got to be able to ensure that they're a partner...Not just that there's a business opportunity but you and they (partners) match well enough to be able to work together. Because if you're very different in what you're trying to achieve - you both may be very good, but working together won't be easy."

Corporate interviewee

"Strategically, you can have partners who disobey the rules, so you either have to stop the partnership or stop them doing it. And some quality processes can be quite hard for some partners to get used to, so we have to do a lot of development with them."

Marketing interviewee

\subsection{Integration and Cooperation}

Integration and cooperation enables individuals, groups, and departments to work together and achieve a common goal (Thorpe \& Morgan, 2007; Hrebiniak, 2009). The university's internal integration and cohesion are also vital for its successful internationalization. The research findings at the present university reflect occurrence of inefficient cooperation among key departments:

"[One staff] would go abroad and meet people and they would say 'oh, we'd like to do a collaboration with you'. And she would come back and pass on the details to the collaborative office (under marketing department) who never did anything with them. [these collaborations] never developed."

Corporate interviewee

Moreover, if the university takes too long to response the opportunities, the momentum and staff's enthusiasm of internationalization may vanish:

“There's a very bureaucratic procedure. They take too long, forever and so it goes on and on and on. It's not very fast in terms of its response time. So it means that sometimes these things just fade away because they're taking too long." 
Marketing interviewee

\subsection{Motivation and Incentives}

Pay for performance is probably the first thing that comes to mind when people think about motivating employees. Awasthi and Pratt (1990) have found that monetary incentives would increase the employees' effort in activities or actions, although this view has been criticized by other scholars (Frey, 1997; Deci et al., 1999; Benabou \& Tirole, 2003; Davies et al., 2004). Internationalization has been conceptualized as an additional load, thus monetary incentives could be considered a kind of compensation for individuals:

Sometimes, allowance delay may erode the academics' cooperation in internationalization because academics sense that they do not get what they work for; consequently, they either stop participating in internationalization or appoint someone else to do it:

"The issue (allowance) comes obviously where something comes on stream mid year and they (corporate) hadn't made that allowance... that was something additional that we (academics) had to do on top of what else we were doing. Part of the transition will be to appoint somebody to do that as part of their role, or bring associate lecturers to deliver [programmes], so we (academics) can actually focus on building up the number of students."

Faculty interviewee

However, if the above statement is correct, that means actually the academics are able to handle the international initiatives, as long as the incentives are delivered on time. In other words, monetary term may act as a primary motivation at work. Then, why does the allowance always delay? Part of the reasons is that the corporate and marketing groups disagree with the effect of incentives. They stress that in fact allowance cannot motivate staff's effort because the underlying reasons of resistance of $\mathrm{HE}$ internationalization are dealing with stress and uncertainty:

"People will be concerned about allowances or workloads, how much time do I get for working with this partner. That will be a genuine concern...But when we (corporate) experimented and we gave people (academics) the allowance, nothing changed. It wasn't to do really with the allowance, it was maybe more down to pressures and 'the unknown'."

Corporate interviewee

Actually, the above concern is highly interrelated with another issue of staff attitude.

4.6 Staff Attitude and Development

A tridimensional (negative) attitude relates to the cognitive dimension that represents how an individual conceptualizes or thinks about change (Oreg, 2006). Research findings show that some staffs are cooperative and enthusiastic about internationalization, while others may resist it due to personal attitude:

"There's a real range of attitudes. There will be some staff who are frightened but also excited and would like to embrace [internationalization] and move forward. There's a whole raft of staff in the middle and then there will 
be some staff at the other end who don't want it, don't want to know, so frightened that they'll bury their heads in the sand."

Corporate interviewee

“...the representation of themselves (academics) is weak. Say for instance, you are going for a fight, and you don't want to fight, you'll not win."”

Marketing interviewee

Attitude leads to reluctant participation in HE internationalization, especially at the faculty level (pointed by marketing group):

"It depends on the attitude of the staff (academics)... if the staff see there is something extra (international initiatives) for them to do they probably just ignore it and I met a lot of problems like this. Different people have got a different attitude."

Marketing interviewee

"There are cases where it's difficult to do, but more often than not it's the people...they (academics) say they can't do [internationalization] because they feel it is too fringe...just messing around the edges. But I think it's probably more to do with attitude."

Marketing interviewee

It is interesting that no faculty staff realizes their attitude causes issue, affects the work of other departments, and consequently impedes international development. But the faculty group does sense the need for staff development:

"We do not gear up to either internationalize the curriculum or deal with international students. We don't have the experience... don't know how and we need a lot of staff development."

Faculty interviewee

“Definitely, I think there's an area about sort of staff development, so that staff can understand the importance of internationalization."

Faculty interviewee 
Certain neutral point of view emerges during interview and states that having issues is common. Any issue emerging here should be considered an opportunity, rather than a problem:

"Every place has its own detailed issues and I don't think these are problems. They are challenges for us. For instance, if students automatically apply and come to the university, we don't need marketing department, we don't need agents, we don't need cooperation from faculties...so it's not a problem, it's an opportunity. If we don't have any problem, nobody will have a job. "

Marketing interviewee

Maybe the above statement is correct. But if all the problems remain unsolved for long, more staff will become frustrated and passive at work. Consequently, there is no sustainable development of HE internationalization.

\section{Discussion}

The research discussed the critical issues of HE internationalization in relation to resource, workload, agent and partnership management, integration and cooperation, motivation and incentives, and staff attitude. The more specific these issues are to the university, departments and individuals, the more efficient and precise action is needed. To certain extent, these empirical issues are interrelated to each other, having a kind of 'domino effect'. For example, international initiatives can overload academics, and overextend their schedules, which may lead to stress and results in passive cooperation or poor integration. But the root of poor integration stems from staff personal attitudes that may or may not be impacted by monetary terms. Limited resource and challenges of agent and partnership management put more pressure on implementation of HE internationalization. Actually, HE internationalization is primarily an internal thing, rather than a set of external factors. Thus, recommendation should also come from the development of institution's internal cohesion. For example, the university should offer more training and interaction opportunity across different departments, share more common values, and foster the employees' willingness to support internationalization. However, attitude relates to personal traits that cannot be changed easily (Gordon, 1991; Hrebiniak, 2009). Changing attitude is a long-term endeavor, and should not start with attitude directly, but through an incremental top-down influence, such as by leadership (Smith, 2006; Self \& Schraeder, 2008). In addition, these critical issues are also applicable and transferable to other similar situations. Therefore, further research will focus on testing these challenges in other universities through quantitative studies. More stakeholders (students, employers, and ministry of education) should be involved in further study to develop a more multilateral reflection on HE internationalization.

\section{Reference}

Altbach, P. G., \& McGill, P. P. (1998). Internationalize American higher education? Not exactly. International Higher Education, 30(4), 36-39.

Audenhove, L. V. (1998). Development co-operation and linkages in higher education: Key issues concerning policy and organization. International Review of Education, 44(5/6), 531-548. http://dx.doi.org/10.1023/A:1003441231514

Awasthin, V., \& Pratt, J. (1990). The effects of monetary incentives on effort and decision performance: Tthe role of cognitive characteristics. The Accounting Review, 65(4), 797-811.

Bakalis, S., \& Joiner, T. A. (2004). Participation in tertiary study abroad programs: the role of personality. International Journal of Educational Management, $18(5), \quad 586-591$. http://dx.doi.org/10.1108/09513540410543420

Bamford, J. (2008). Strategies for improving international students' academic and cultural experiences of UK study. In R. Atfield, \& P. Kemp (Eds.), Enhancing the International Learning Experience in Business and Management, Hospitality, Leisure, Sport, Tourism (pp. 58-67). Newbury: Threshold Press.

Barbosa, I., \& Cabral-Cardoso, C. (2007). Managing diversity in academic organizations: A challenge to organizational culture. Women in Management Review, 22(4), 274-288. http://dx.doi.org/10.1108/09649420710754237 
Bataeineh, M. (2008). A Historical Investigation on the Establishment and Development of Higher Education in Jordan (Doctorate dissertation, Northern Illinois University, Illinois, United States).

Baxter, P., \& Jack, S. (2008). Qualitative Case Study Methodology: Study Design and Implementation for Novice Researchers. The Qualitative Report, 13(4), 544-559.

Benabou, R., \& Tirole, J. (2003). Intrinsic and extrinsic motivation. Review of Economic Studies, 70(3), 489-520. http://dx.doi.org/10.1111/1467-937X.00253

Boyle, B., McDonnell, A., Mitchell, R., \& Nicholas, S. (2012). Managing Knowledge in Internationalizing Universities through Foreign Assignments. International Journal of Education Management, 26(3), 302-312. http://dx.doi.org/10.1108/09513541211213363

Brandenburg, U., \& De Wit, H. (2011). The end of internationalization, International Higher Education (Vol. 62, Winter, pp. 29-33). Center for International Higher Education Boston College.

Brown, R. (1998). Developing effective overseas partnerships: Future lessons from Britain. Journal of International Education, 9(3), 12-19.

Chandler, D. (1998). Semiótica para Principiantes (trans. Vanessa Hogan Vega \& Iván Rodrigo Mendizábal). Quito. Ecuador: Ediciones Abya-Yala/Escuela de Comunicación Social de la Universidad Politéchnica Salesiana.

Cheung, C. K., Yuen, W. W., Yuen, Y. M., \& Cheng, Y. C. (2011). Strategies and policies for Hong Kong's higher education in Asian markets, Lessons from the United Kingdom, Australia, and Singapore. International Journal of Educational Management, 25(2), 144-163. http://dx.doi.org/10.1108/09513541111107579

Cohen, L., \& Manion, L. (1992). Research Methods in Education. London: Routledge.

De Wit, H. (2011). Trends, Issues and Challenges in Internationalization of Higher Education. Retrieved from http://www.carem.hva.nl/wp-content/uploads/2011/10/Trends-Issues-and-Challenges_Hans-de-Wit1.pdf

Deci, E., Koestner, R., \& Ryan, R. (1999). A meta-analytical review of experiments examining the effects of extrinsic rewards on intrinsic motivation. Psychological Bulletin, 125(6), 627-668. http://dx.doi.org/10.1037/0033-2909.125.6.627

Eldik, K. (2011). Challenges in the internationalization of higher education. Retrieved from http://heic.info/assets/templates/heic2011/papers/13-Kamal_Eldik.pdf

Elkin, G., Farnsworth, J., \& Templer, A. (2008). Strategy and the internationalization of universities. $\begin{array}{llll}\text { International Journal of Educational } & \text { Management, 22(3), }\end{array}$ http://dx.doi.org/10.1108/09513540810861874

Fairclough, N., Jessop, R., \& Sayer, A. (2004). Critical realism and semiosis-critical realism, discourse and deconstruction. New York: Rouotledge.

Frey, B. S. (1997). Not Just for the Money: An economic theory of personal motivation. Cheltenham: Edward Elgar.

Gordon, G. G. (1991). Industry determinants of organizational culture. Academy of Management Review, 16(2), 396-415.

Harris, S. (2008). Internationalizing the University. Educational Philosophy and Theory, 40(2), 346-357. http://dx.doi.org/10.1111/j.1469-5812.2007.00336.x

Harris, S. (2009). Challenges and possibilities facing European higher education. Papers, Revista de sociologia, Department de Sociologia, Universitat Autónoma de Barcelona.

Hodges, L. (2007, September 6). Should universities build campuses in the People's Republic China or set up joint degrees with Chinese institutions? Retrieved from http://www.independent.co.uk/news/education/higher,The Independent

Hrebiniak, L. (2009). Making Strategy Working. New Jersey: Wharton School Publishing.

Huang, F. (2006). Internationalization of curricula in higher education institutions in comparative perspectives: Case studies of China, Japan and The Netherlands. Higher Education, 51(4), 521-539. http://dx.doi.org/10.1007/s10734-004-2015-6

International Association of Universities (IAU). (2005). Internationalization of Higher Education: New Directions, New Challenges, 2nd Global Survey. Retrieved from 
http://www.iau-aiu.net/content/iau-global-surveys

Ivancevich, J. M., \& Gilbert, J. A. (2000). Diversity management: time for a new approach. Public Personnel Management, 29(1), 75-92.

Jiang, N., \& Carpenter, V. (2011). Market entry dynamic framework for higher education internationalization. Journal of International Education in Business, 4(2), 141-158. http://dx.doi.org/10.1108/18363261111189531

Jiang, N., \& Carpenter, V. (2013). A case study of issues of strategy implementation in internationalization of higher education. International Journal of Educational Management, 27(1), 4-18. http://dx.doi.org/10.1108/09513541311289792

Jiang, N., \& Carpenter, V. (2013). Faculty-specific factors of degree of HE internationalization: An evaluation of four faculties of a post-1992 university in the United Kingdom. International Journal of Educational Management, 27(3), 242-259. http://dx.doi.org/10.1108/09513541311306468

Jones, E. (2008). World-wide horizons at Leeds Metropolitan University. In R. Atfield, \& P. Kemp (Eds.), Enhancing the International Learning Experience in Business and Management, Hospitality, Leisure, Sport, Tourism (pp. 1-12). Newbury: Threshold Press.

Kavale, K. A., \& Forness, S. R. (1996). Social skill deficits and learning disabilities: A meta-analysis. Journal of Learning Disabilities, 29(3), 226-237. http://dx.doi.org/10.1177/002221949602900301

Killick, D. (2009). Graduates and global citizens perspectives on teaching and learning. Paper presented at the Internationalization of the Curriculum Workshop, Regents College, London, 11th March.

Knight, J. (2004). Internationalization remodeled: Definition, approaches, and rationales. Journal of Studies in International Education, 8(1), 5-31. http://dx.doi.org/10.1177/1028315303260832

Knight, J. (2007). Internationalization brings important benefits as well as risks. International Higher Education, 46(Winter), 8-10.

Knight, J. (2008). Higher education in turmoil. The changing world of internationalization. Rotterdam: Sense Publishers.

Lee, J., \& Rice, C. (2007). Welcome to America? International student perceptions of discrimination. Higher Education, 53(3), 381-409. http://dx.doi.org/10.1007/s10734-005-4508-3

Liff, S. (1999). Diversity and equal opportunities: Room for a constructive compromise? Human Resource Management Journal, 9(1), 65-75. http://dx.doi.org/10.1111/j.1748-8583.1999.tb00190.x

Liff, S., \& Wajcman, J. (1996). Sameness and difference revisited: Which way forward for equal opportunity initiatives? Journal of Management $\quad$ Studies, $\quad 33(1), \quad 79-94$. http://dx.doi.org/10.1111/j.1467-6486.1996.tb00799.x

Lowe, M. (2008). More than study: Exploring relationship-building with overseas students. In R. Atfield, \& P. Kemp (Eds.), Enhancing the International Learning Experience in Business and Management, Hospitality, Leisure, Sport, Tourism (pp. 143-152). Threshold Press: Newbury.

Maringe, F. (2009). Strategies and challenges of internationalization in HE: An exploratory study of UK universities. International Journal of Educational Management, 23(7), 553-563. http://dx.doi.org/10.1108/09513540910990799

Maringe, F., Lumby, J., \& Morrison, M. (2007). Leadership diversity and decision making in FE colleges. Working paper, Centre for Excellence in Leadership, Lancaster.

Naidoo, R., \& Jamieson, I. (2005). Knowledge in the Marketplace: The Global commodification of Teaching and Learning in Higher Education. In P. Ninnes, \& M. Hellsten (Eds.), Internationalizing Higher Education, Critical Explorations of Pedagogy and Policy. Comparative Education Research Centre, the University of Hong Kong. http://dx.doi.org/10.1007/1-4020-3784-8_3

Niser, J. C. (2010). Study abroad education in New England higher education: A pilot survey. International Journal of Educational Management, 24(1), 48-55. http://dx.doi.org/10.1108/09513541011013042

OECD. (2004). Internationalization and Trade of Higher Education-Challenges and Opportunities. Organization for Economic Co-operation and Development, Paris.

Oreg, S. (2006). Personality, context, and resistance to organizational change. European Journal of Work and Organizational Psychology, 1(1), 73-101. http://dx.doi.org/10.1080/13594320500451247 
Pritchard, R. M. O., \& Skinner, B. (2002). Cross-cultural partnerships between home and international students. Journal of Studies in International Education, 6(4), 323-354. http://dx.doi.org/10.1177/102831502237639

Schoemaker, P. J. H. (2008). The future challenges of business: Rethinking management Education. California Management Review, 50, 119-139. http://dx.doi.org/10.2307/41166448

Self, D. R., \& Schraeder, M. (2008). Enhancing the success of organizational change-Matching readiness strategies with sources of resistance. Leadership and Organization Development Journal, 30(2), 167-182. http://dx.doi.org/10.1108/01437730910935765

Seymour, D. (2002). University hospitality education for international management: A case of wasted opportunities? Journal of Hospitality, Sport, Tourism and Leisure Education, 1(2), 3-13. http://dx.doi.org/10.3794/johlste.12.5

Shubert, J. (2004). Why we shouldn't treat higher education as a commodity. Retrieved from http://www.yorku.ca/yorkint/about/resources/lecture3.htm

Sidhu, R. (2007). GATE and the new developmentalism: Governing transnational education. Comparative Education Review, 51(2), 203-228. http://dx.doi.org/10.1086/512020

Smith, I. (2006). Continuing professional development and workplace learning-15 achieving successful organizational change-do's and don'ts of change management. Library Management, 27(4/5), 300-306. http://dx.doi.org/10.1108/01435120610668232

Stake, R. E. (1995). The art of case study research. Thousand Oaks, CA: Sage.

Stemler, S. (2001). An overview of content analysis. Practical Assessment, Research and Evaluation, 7(17), 24-36.

Strauss, A., \& Corbin, J. (1990). Basics of Qualitative Research. Newbury Park: Sage.

Teichler, U. (1996). Student mobility in the framework of ERASMUS: Findings of an evaluation study. European Journal of Education, 31(2), 153-179.

Teichler, U., \& Maiworm, F. (1996). The ERASMUS Experience. Major Findings of the ERASMUS Evaluation Research Project. Luxemburg-Kassel: EC-DGII-Universität Kassel. Retrieved from http:/europa.eu.int/comm/education/socrates/erasmus/public.html

Thomas, H., \& Cornuel, E. (2012). Business School in Transition? Issues of Impact, Legitimacy, Capabilities and Re-invention. Journal of Management Development, 329-335. http://dx.doi.org/10.1108/02621711211219095

Thorpe, E. R., \& Morgan, R. E. (2007). In pursuit of the 'ideal approach' to successful marketing strategy implementation. European Journal of Marketing, 41(5/6), 659-677. http://dx.doi.org/10.1108/03090560710737679

Thorstensson, L. (2001). This business of internationalization: The academic experiences of Asian MBA international students at the University of Minnesota's Carlson School of Management. Journal of Studies in International Education, 5(4), 317-340. http://dx.doi.org/10.1177/102831530154004

Van Damme, D. (2001). Quality issues in the internationalization of higher education. Higher Education, 41(4), 415-441. http://dx.doi.org/10.1023/A:1017598422297

Yen, W. J., \& Stevens, P. (2004). Taiwanese students' perspectives on their educational experiences in the United States. International Education Journal, 5(3), 294-307.

Yin, R. K. (2003). Case study research: Design and methods (3rd ed.). Thousand Oaks, CA: Sage.

\section{Copyrights}

Copyright for this article is retained by the author(s), with first publication rights granted to the journal.

This is an open-access article distributed under the terms and conditions of the Creative Commons Attribution license (http://creativecommons.org/licenses/by/3.0/). 